\title{
Surviving the African Anthropocene: Dilman Dila's Mutational Aesthetics
}

\author{
TIMOTHY SEAN WRIGHT \\ Bilkent University \\ timothy.sean.wright@gmail.com
}

\begin{abstract}
Matthew Omelsky has recently coined the term "African Anthropocene" to describe how the intertwined crises wrought by global capitalism and man-made ecological disaster have disproportionately affected the African continent. This paper discusses a short story collection by the Ugandan writer Dilman Dila, A Killing in the Sun (2014), as one instance of an African aesthetics that uniquely registers and responds to this dual crisis. I focus in particular on the "vampire story" that opens this collection, arguing that Dila not only reinvents, but, in critical ways, "mutates" the canonical Euro-American vampire figure. In reimagining the aristocratic European vampire as a mutant, genetically modified swarm of mosquitos, Dila's story suggests new, environmental forms of the monstrous emerging at the confluence of ecological catastrophe and corporate neocolonialism. At the same time, I show how Dila's fiction draws on the history of colonialism in Africa in imagining modes of survival within this vampiric ecology. In order to unpack the political implications of what I call Dila's "mutational aesthetics," I trace Dila's attempts to imagine forms of human-nonhuman entanglement that delink from a Western episteme and its ideological carapace of "the human," providing instead post-humanist visions of survival and refuge.
\end{abstract}

7 he scene is a remote Ugandan town. A plague of outsized vampire mosquitoes-the mutant descendants of a benign species engineered to be unable to carry malaria-has desiccated the vicinity's mammalian life and blankets all remnants of human habitation in a black pall. The two human survivors, an infant and the grown man who has rescued him, take shelter in a grove of orange trees, whose pungent leaves keep these insectoid vampires temporarily at bay. A rescue helicopter arrives; it is promptly engulfed by the swarm. No matter-the 
man has no interest in being saved by the very people who created the plague in the first place.

This is the outline of Dilman Dila's short story "The Leafy Man," a tale that, for all the dislocating unfamiliarity of its referents, circles around the familiar figure of the vampire. Dila's vampire, however, has been rendered-at least to readers schooled in the Euro-American canon of vampire lore-almost unrecognizable. Reinvented as an ecological entity, these vampires are the dominant force in an environment in which the human is no longer master but instead consigned to provisional forms of survival. That is to say, Dila's story imagines, on the generic template of the European vampire tale, a new form of the monstrous that emerges in the age of human-engineered planetary interventions.

Matthew Omelsky has recently used the term "African Anthropocene" to describe the unique form environmental catastrophe has taken on the African continent. Drawing on a range of both postcolonial and ecological thinkers, Omelsky writes of a new paradigm of African "postcrisis fiction" that has emerged in response to the dual crises of ecology and capitalism. This fiction, writes Omelsky, exhibits a "nascent politics and aesthetics of the African Anthropocene," the particular form in which global ecological crisis impacts a continent already subject to some five centuries of colonial depredation (36). In the African Anthropocene are linked the dual crises of modernity. First, the crisis of capitalism, with its expansion into all corners of the planet and its relentless cycles of boom and bust; second, the crisis of ecology provoked by geologically visible human intervention into the planet's composition. The term thus unites the two limiting conditions of global modernity: the finitude of our planetary habitat and the long history of global depredation-slavery, colonization-enabled by the racial hierarchization of human life. In addition, Omelsky's term suggests that African fiction, drawing on a long history of catastrophe, is uniquely able to represent and respond to this dual crisis.

Dila's story-with its layerings of neocolonial and environmental catastrophe and its imaginative investment in radical forms of survival within this catastrophe-falls squarely within Omelsky's framework. It is a critique of a kind of Western medical "benevolence" that accompanied colonialism and has persisted in new forms into the post-independence period. But it is also something more: a critique of the very categories through which human life on the planet is imagined. These categories have always depended on the manufacture of an other ("Nature," and the racial ideologies that have associated non-European peoples in greater proximity to this Nature) in order to retain their own conceptual purity and coherence. As I will show, Dila's story takes up the figure of the vampire not simply to represent new forms of colonialism, but to rethink that very divide between "Man" and "Nature" from the perspective of the African Anthropocene.

Through a reading of Dila's story, I want to think about how the rubric of the African Anthropocene might help us understand what Africa does to one particular monster of the Western imagination: the vampire-a figure with a wellestablished history, across its various iterations in Europe, America, and Africa, as a colonial or colonizing being. In particular, I want understand how and to what end Dila ecologizes the vampire: that is, how Dila takes a literary figure associated with an aristocratic hyper-individualism and enmeshes it within an environment. Key to understanding what Dila does to the vampire is understanding the logic of mutation at work in Dila's fiction. Mutation, I will argue, is not simply a 
theme within Dila's stories; rather, it is the fundamental structuring trope of Dila's literary imagination. Indeed, Dila's stories display a "mutational aesthetics": an aesthetics that emphasizes and embraces radically nonlinear and a-teleological forms of metamorphosis. Dila's story thus represents a break with many of the more traditionally humanistic themes that predominate in earlier waves of African fiction. Concerned neither with the struggle for national emancipation, nor with postcolonial disillusionment, Dila's fiction turns instead to a non-humanist, quasibiological imaginary of survival.

I will pursue my argument as follows. First, I show how, in Dila's figuration, the vampire becomes an "ecological" being. By ecological I do not mean "natu-

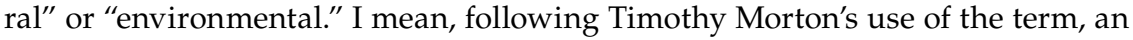
interconnectedness or enmeshment that precedes the individual subject. I focus on Dila's reinvention of the vampire as a fully ecological being-his imagining of, in effect, a vampiric ecology rather than a discrete vampire. Dila's imagining of a genetically engineered mosquito that mutates and destroys the very environments on which it depends is an attempt, I argue, to invent a monster adequate to the crisis of the African Anthropocene. The second part of this essay examines Dila's imagining of forms of delinking and survival within this ecology. I argue that Dila's "mutational aesthetics" are an emphatically material way of imagining new (and often violent) assemblages of the human and nonhuman directed to survival within a catastrophic world. Finally, I argue that Dila's vampire story, for all its disruption and mutation of generic European categories of the monstrous, ultimately falls within a long-standing tradition of autochthonous African vampire tales-a tradition concerned not with heroic romances of national liberation, but rather with the everyday business of survival.

\section{ECOLOGIZING THE VAMPIRE}

An archetypal monster of Euromodernity, the vampire has not travelled to Africa with the same ease that it has to North America, where it has been subject to manifold reinventions. The African vampire descends not from the seductive, fanged aristocrat of the European imagination, but from a long line of colonial bureaucrats with unchecked appetites and extractive desires. While in the Euro-American tradition the vampire possesses a semantic fluidity-polymorphous perverse deviant in Stoker, maligned outsider in Anne Rice, and so on-in the African context, it exists under the long shadow of empire. The vampire of the African imagination, as I discuss in the penultimate section of this article, is almost invariably a colonial being. Dila's swarming, mutant, village-decimating mosquito-vampire-referred to by the narrator throughout simply as "Miss Doe" — can be located within this tradition of the colonial vampire. While the seeds for Dila's story were almost certainly planted by the real-life introduction of genetically modified mosquitos in Uganda (to combat the Zika virus), by semantically linking this mosquito with the vampire, the story takes what might have been a simple morality tale and turns it into a penetratingly original reinvention of and commentary on the vampire and the kinds of worlds it is imagined to inhabit. A figure with rich symbolic resonance in both European and African literature, the figure of the vampire allows Dila to offer new insight into the specific ways in which colonial power has mutated in the early 21 st century. 
Before moving on to the narrative elements of the story, let me then dwell at some length on the characteristics of the monster Dila has imagined to populate his apocalyptic world. As a creature that, in the words of Elleke Boehmer, "feeds upon the substance of those whose life it requires to live and thrive," the vampire is if anything an overdetermined figure for the colonial enterprise, a figure for both the extractive rapacity of colonialism as well as its anxieties and paranoias (vii). ${ }^{1}$ Stephen Arata characterizes Bram Stoker's Count Dracula, the archetypal European vampire, as effectively a "colonizing animal" who embodies a fin de siècle British "anxiety of reverse-colonisation" (623); Franco Moretti has similarly argued that Count Dracula is quite specifically a figure for the emergence of new forms of monopoly capital (74). But Dila's "Miss Doe" possesses no morphological debt to this archetypal colonizer. Indeed, Miss Doe bears no resemblance to the human; nor, being a species independent of human agency, does she participate in any human political or economic projects. Unlike the European vampire, she does not colonize, convert, or appropriate human bodies; she simply eliminates them. She is thus not readable as a simple allegory of colonialism. What then does one make of her?

As a starting point, we can observe that Dila's vampire mosquitos are vampires imagined through an ecological prism. Timothy Morton writes of the "ecological thought" that it is fundamentally an idea-or rather, experience-of radical interconnectedness. This kind of interconnectedness has little to do with Freud's "oceanic feeling" or the various forms of transcendence one finds in the tradition of nature writing, but is instead bound up with a range of jarring, destabilizing, or disruptive affective states. "[T]he ecological thought is intrinsically dark, mysterious, and open" writes Morton; it "includes negativity and irony, ugliness and horror" (16). Indeed, an authentic ecological narrative would for Morton take the form not of nature writing but of a noir film: "the noir narrator begins investigating a supposedly external situation, from a supposedly neutral point of view, only to discover that she or he is implicated in it" (16-17). To think of the vampire in Morton's ecological sense is to think of it as entangled with the human world, rather than as, conventionally, an alien intrusion into it-an intrusion that can be banished, "blotted out," in order to restore a stable order, as Count Dracula is in Bram Stoker's classic novel.

Unlike the conventional humanoid vampire, Miss Doe is an environmental entity: an unvariegated blanket that covers the discrete traces of human habitation on the landscape. Although, like the humanoid vampire, the mosquito punctures human skin to feed off blood, it is an ambient creature: conventionally assumed to be a backdrop to everyday environments rather than a protagonist within them. Miss Doe is at home in daylight and wilderness, rather than the internal, subterranean, gothic geographies of the Euro-vampire. She lacks the discrete identity of the traditional vampire: she is a "thick cloud" that conceals individuation, color, and human habitation. The roar of the swarm sounds like a hailstorm; as she moves from her perch, she resembles "rain in reverse" (15). She devours all, including, ultimately, the forces that created her. Rather than a discrete being navigating through an environment, she is an environment, an entity enmeshed in and dependent on an ecosystem, in a crucial way independent of human agency and volition.

Miss Doe's female gender is also key. Unlike the conventional vampire, which can only perpetuate itself as a species by "turning" human beings into vampires, 
Miss Doe is a fundamentally reproductive being. She is able to auto-reproduce and not only auto-reproduce, but auto-mutate. ${ }^{2}$ Rather than being stripped of reproductive powers, she possesses them in abundance. Here, we find under the name vampire an entirely different phenomenon: a viral, metamorphic, propulsive swarm.

There is a final and crucial detail that renders Miss Doe more than simply an ecological entity, but specifically a creature of the African Anthropocene. We are told, as the story progresses, that Miss Doe has her origins as a medical product. The vampire mosquitos of Dila's story are a genetically modified variety introduced by the "Pest and Germ Corporation" ("PGCC"), a multinational entity contracted by the Ugandan government. This mosquito is engineered to be unable to carry the malaria virus and to have no need for blood, the intent being that it outpopulate and displace the anopheles. As in so many modern fictions on the Promethean theme, from Frankenstein to The Island of Dr Moreau to Jurassic Park, nature does not submit politely to control. Miss Doe undergoes a chain of mutations, every attempt to exterminate her only driving her to greater degrees of monstrosity, as she metamorphoses from benign defanged prophylactic to a monster "as big as [a] thumb" (5) whose appetite for blood returns redoubled (the unmodified mosquito requires blood only for purposes of reproduction, not nourishment).

Miss Doe is the classic case of the cure that is worse than the disease. At the most obvious level, she is a critique of the kind of "benevolent" medical technology that accompanied, and was often used to legitimize, colonial projects. But the critique is not simply that Western medicine all too often acts as the handmaiden to forms of neocolonialism. It is rather an epistemic critique that concerns the fundamental knowledge categories embedded within this medical project. In Miss Doe, neocolonial corporate predation appears in conjunction with large-scale human intervention into the natural world-not in the form of global climate change, but in the form of a genetic engineering and species-modification project that is, in effect, a hypermodern iteration of a far older environmental imperialism that aimed to subdue and domesticate the land. The story thus critiques a long history of imperial ventures that drew confidence from their sense of technical mastery over nature: from environmental control. This was most acutely the case in Africa, represented in the view of Sir Charles Eliot, an early 20th-century British diplomat and at one point Commissioner of British East Africa: "the problem with Africa was that its environment required to be controlled and transformed" (qtd. in MacKenzie 216).

Through Miss Doe, whose wild mutations result in a creature very distant to that imagined in the Western laboratory, Dila's story parodies this desire to tame Africa's ostensible unruliness. Miss Doe represents a new form of being that escapes the classical Enlightenment episteme: neither completely "natural" nor completely "human," she is the kind of ontologically disturbing entity that is increasingly prevalent (or at least increasingly being apprehended) in the age of the Anthropocene. In his book-length study of human-induced geological change, The Great Derangement, Ghosh writes of what he calls the "environmental uncanny": a category of the uncanny lacking any of the human referents exploited by conventional gothic literature. Describing his encounter with a freak tornado that swept through northern Delhi in the late 1970s-one of the increasingly common aberrant weather events precipitated by anthropogenic climate change-Ghosh is captured by the image of the tornado's "eye." "[W]hat had happened at that moment 
was strangely like a species of visual contact, of beholding and being beheld," writes Ghosh, "[a]nd in that instant of contact, something was planted deep in my mind, something irreducibly mysterious ... something that was not a property of the thing but of the manner in which it had intersected with my life" (15). The term Ghosh settles on to describe this encounter-borrowing from Timothy Morton-is "uncanny." Uncanny because "in these encounters we recognize something we had turned away from: that is to say, the presence and proximity of nonhuman interlocutors" (30).

In the "environmental uncanny," humans encounter an anthropogenic environment that has broken free of its origins in human action and taken on a life of its own. While uncanniness has been a staple component of the gothic mode of literature in the West for at least the past three centuries-where, as Nancy Armstrong has suggested, it signifies those impermissable excesses that modernity has banished in its production of a normative liberal subjecthood-this ecological modality of the uncanny presents us with something qualitatively different. ${ }^{3}$ Ghosh writes:

The environmental uncanny is not the same as the uncanniness of the supernatural: it is different precisely because it pertains to nonhuman forces and beings. The ghosts of literary fiction are not human either, of course, but they are certainly represented as projections of humans who were once alive. But ... freakish weather events like the Delhi tornado, have no human referents at all. (32)

Much of the cultural and philosophical production of the West over the past five centuries has unfolded under the presumption that the human individual exists against a stable background called "nature." Ghosh's uncanny encounter with the Delhi tornado calls into question this rigid distinction, suggesting instead a mutual implication of human beings and the most catastrophic emanations of the natural world. In this experience of the environmental uncanny, one experiences the reanimation of a seemingly de-animated world. That is, the Anthropocene appears to Ghosh as a rupture in an epistemic regime in which the human subject stands apart from the natural world.

This crisis, then, yields fundamentally new forms of the monstrous. By "monster," "monstrous," "monstrosity" - terms I will lean on repeatedly in this paper-I mean a form of being that can be neither classified nor anticipated from within preexistent epistemic matrices. In the age of the Anthropocene, one form the monstrous can take is that which disrupts or blurs those boundaries between "Man" and "Nature" fortified over the course of Western modernity. Ghosh's environmental uncanny captures something of the peculiar qualities of Miss Doe, whose placeholder name hints at the unknown quantity buried within her biological makeup. Dila's vampires of the Anthropocene are versions of Ghosh's tornado's eye that looks back at the human world: a seemingly natural catastrophe that is bound up with human actions. In her geospatial saturation, Miss Doe constitutes an active, animate environment. Dila's story depicts a vibrant universe of bodies, things, and actions, all subject to continual transformation. Not only do the human subjects of this story radically transform themselves in order to survive-as I will discuss in the following section-but the "vampires" too are monstrous and mutating beings bearing scant resemblance to the aristocratic and rigid vampire of the European imagination. ${ }^{4}$ 
Bruno Latour has argued that, in the Anthropocene, the world appears as once more animated, a space in which agency is no longer restricted to humans but is distributed in multiple ways. "To be a subject," writes Latour, "is not to act autonomously in front of an objective background, but to share agency with other subjects that have also lost their autonomy" (5). This is the case in Dila's story, in which there is no passive backdrop against which the human protagonists of this world "act." Miss Doe is indeed a putative backdrop that takes on an agency of its own. At the same time, the human characters in the story lose their unique autonomy, becoming agents in a world of agents. In its moments of human-nonhuman recognition, Dila's story operates anthropocenically, according to the "dark" mode of ecological narrative advocated by Morton, in which the protagonist discovers his own implication in an ostensibly nonhuman natural world. Dila's view of the natural world is thus diametrically opposed to what Anna Tsing has called the idea of the "plantation": a conception of the environment as something that can be systematically compartmentalized, controlled, and harnessed by humans within a narrative of progress.

\section{MUTATIONAL AESTHETICS}

Dila's story can be said to "mutate" the traditional categories of monstrosity consolidated in Western modernity. This mutational logic is most clearly visible in what the story does with the genre of vampire fiction itself. Even though she is continually described in the story as a "vampire," it might be a categorical mistake to view Miss Doe as what is by now, in the early 21st century, a monster that has been comfortably domesticated. Miss Doe is a creature so morphologically distant from the Euro-vampire that, were it not for her penchant for blood and the insistent narratorial use of the term "vampire," no point of generic connection would seem possible. (The story's continued recourse to the term "vampire" might indeed mark a way for the narrator to cling onto a familiar world - and a familiar monster - as all other frames of reference collapse.) Instead, as I have been suggesting, Miss Doe is a creature that unsettles and short-circuits discrete Western categories of the monstrous, amalgamating a variety of discrete Western science fictional subgenres into a singular anthropocenic monster.

Miss Doe is in fact a syncretic and ontologically unstable monster that binds together what were originally separate categories of the monstrous formulated in the modern European imagination. She is, as I have suggested, a mutant, ecological descendent of Count Dracula. But she is also a descendent of the human-engineered monster in Mary Shelley's Frankenstein. Like Frankenstein, "The Leafy Man" is a tale of scientific overreach in which a human creation takes on unexpected agency and enters into a rivalry with its creator. Like Frankenstein's monster, Miss Doe is nameless, and like the monster, her desires are totalizing: she will not stop until other life is destroyed. Finally, Miss Doe's provenance is traceable to a third Western literary monster, this time inhuman: the plagues of Defoe, Camus, and Mary Shelley's apocalyptic novel The Last Man. In these works-especially Shelley's - the human being, proud with pretensions of self-possession and mastery, is rendered a species staving off extinction.

One way to read Dila's story is as a story about the mutation of genre itself. Victor Frankenstein's nameless monster, animated from an assemblage of human 
body parts looted from mortuaries, and Stoker's Dracula are of course the two iconic monsters of European modernity. Franco Moretti reads the emergence of these twin monsters as representing the fissure between labor and capital and notes that "Dracula and Frankenstein, with rare exceptions, do not appear together. The threat would be too great, and this literature, having produced terror, must also erase it and restore peace" (68). It is no coincidence, to my mind, that in Miss Doe are synthesized categories of the monstrous that exist discretely-that must exist discretely-in European modernity. For in the African Anthropocene are visibly united those intertwined epochs of global modernity that Donna Haraway insists must be thought together: the Anthropocene (the age of human geological agency, the archetypal monstrous form of which is Frankenstein's monster), the Capitalocene (the age of capitalism, the archetypal monstrous form of which is Count Dracula), and the Plantationocene (the age of the vast terraforming and domestication of the natural world, the monstrous form of which is natural disaster, plague).

Of course, one could argue at this point that "The Leafy Man" is not a vampire story at all. But it is worth noting that, amid this splicing and deformation of discrete Euromodern categories of monster, a classically vampiric figure is by no means absent from this story. It is played by PGCC, the corporation that creates Miss Doe. The tell-tale sign is PGCC's secondary modification to Miss Doe: a restriction in the mosquito's mobility that will allow PGCC to charge per square mile. It is for this reason that the vampire is confined to a single village and has not devoured the continent (although further mutations, it is speculated, might allow for greater mobility). To what extent Dila's portrait of PGCC is a realistic portrait of the histories of corporate medicalization or "benevolent" intervention in Africa is beside the point. PGCC's role is to stand in the symbolic space of the traditional vampire: an entity that flourishes through the extraction of human vitality. Even their attempted rescue of the village's human survivor, Japia, falls into this paradigm: Japia is valued as a resource because of the knowledge he holds about their product, Miss Doe.

Relentlessly extractive yet troubled by any life form that might breach their boundaries or render them vulnerable, the PGCC agents who fly in by helicopter are representatives of what Nedine Moonsamy has called the "sterile utopias" of the Western imagination. ${ }^{5}$ Their white Hazmat suits exteriorize nature and symbolize the fortification of the human as sovereign subject (the whiteness of these fortified bodies is surely no accident). The chemical repellent they spray, which proves ineffectual against Miss Doe but wilts the orange leaves that serve as Japia's shield against her, is a mode of intervention that gains confidence through the domination over nature. Theirs is a universalizing knowledge that, on the one hand, overwrites the pragmatic, non-monetizable knowledge emerging from Japia's observations (orange tree leaves are readily available and not as yet copyrightable) and, on the other, aims to produce a world free of contagion and risk, a world in which the "human" is autonomous: omnipotent over and severed from the complex ecologies in which it is embedded.

Dila's story, then, is fundamentally a story of mutation: the mutation of "Nature" into something other-than-Nature, the mutation of "Man" into something other-than-human, and the mutation of genre itself into something capable of registering the new forms of perception and being engendered in the 
Anthropocene. I use the term mutation-rather than "transformation" or "metamorphosis" - advisedly. First, mutation signifies a form of transformation latent within the material matrix of the present, one whose trajectory does not unfold in a linear or teleological fashion. That is, mutation describes a transformation whose endpoint cannot be predicted beforehand. Second-in the same way that Dila's fiction tends to begin in the mode of political or national allegory and culminate in individual transformations of the human organism-mutation shifts emphasis from the ideological and the historical to the biological and organic. It describes, quite simply, the means by which organisms either adapt to an environment or perish. ${ }^{6}$

I draw here, on one hand, from recent writings by Anna Tsing, who has counseled an "art of living on a damaged planet," and from Donna Haraway. Donna Haraway, paraphrasing Tsing, writes that the "inflection point between the Holocene and the Anthropocene might be the wiping out of the refugia from which diverse species assemblages ... can be reconstituted after major events" (159). If the Holocene is the era in which refuge abounded, the Anthropocene is the era of refugees, both human and nonhuman. The question of refuge is, for Haraway, central. The task she sees placed before the human world is that of cultivating "imaginable epochs to come that replenish refuge" (160). A glimpse of refuge appears in Omelsky's essay on post-crisis African fiction, where he uses Franz Fanon's notion of the "new human" —of the "thrownness towards a contingent ontology" (46) — to speak of African imaginings of "reconstituted life" post-catastrophe. ${ }^{7}$ However, the kinds of futures that Dila imagines appear-at least to my mind-to swerve away from Fanon's new human toward something more radically precarious and less "human."

I read Dila's futures as akin to those described by Anna Tsing in her study The Mushroom at the End of the World. Tsing sees in the global spread of the matsutake mushroom - a delicacy that has taken root in industrial plantations gone to waste-profound ramifications for how we think of grand narratives of human progress. For Tsing, these mushrooms, and the motley transnational community of their pickers, constitute new assemblages of life arising in ruins of late capitalism. Tsing's study reorients our understanding of human survival. Our conventional narrative of survival, writes Tsing, is heroic: a story of domination against all odds, of the reconstitution of the human subject as a self-contained, autonomous entity, stronger than before, part of a grand architecture of historical progress. Yet in these communities Tsing sees a different kind of survival: survival as a practice of living in and making meaning from ruins.

Like Tsing, Dila is interested in modes of living in crisis, rather than forms of reconstituted humanity after crisis. His stories contain none of those moments of transcendence in which a character is able to view their struggles and sufferings from a triumphal perspective of overcoming; nor do they contain moments in which protagonists resign themselves to an ineluctable fate. His imagination is attracted instead to the pragmatic business of survival: instead of transcendence we find moments of encounter and collaboration with forms of radical otherness. This plays out in Dila's reworking of the vampire tale. The vampire apocalypse has happened. Rather than the banishment of a vampiric intrusion into the human world, Dila's is a story of the precarious survival of the human in an overwhelmingly vampiric world-a world from which there is little refuge and seemingly no 
escape. The story's investments are in imagining possibilities for human life within a world in which the human is on the wane.

This is evident in Dila's descriptions of his protagonist, Japia. As we are introduced to him, Japia is described as a "moving shrub," his legs like a "sponge" and his body "hollow." Grey "blossom[s]" in his hair, dreadlocks "germinat[e]," and wrinkles "tak[e] root" (2-3). This botanical aesthetic is made literal in Japia's leafiness: his need to cover himself in a protective blanket of orange leaves to ward off Miss Doe. The porous borders and biological dirtiness of Dila's world, standing in stark contrast to the sterility of PGCC, implicitly constitute a counter-topos to the antiseptic world-modification attempted by PGCC.

Japia's botanization is part of a broader imaginary of precarious refuge within Dila's writing. Taken as a whole, Dila's collection (A Killing in the Sun, from which "Leafy Man" is drawn) presents the reader with a set of constrained death-worlds striated by imbalances of power-racially divided, militarily controlled, colonized, or neocolonial-into which startling and unexpected lines of flight open. Two of Dila's most striking stories in this respect, "Itanda Bridge" and "The Yellow People," conclude with visions of what Dila, drawing from biological discourse, calls endosymbiosis: the process by which one life form evolves to exist inside another one. In both stories, alien refugees from distant planets colonize human bodies and dwell inside them. These human-alien hybrids now exist in radically new, previously uninhabitable, environs: at the bottom of a lake (where humans are rewired by their alien inhabitants to survive in submarine environments), or underground (where human corpses are repurposed as functional bodies).

In Dila's use of it, endosymbiosis is a biologically inflected update on the classic horror trope of body snatching. Endosymbiosis is clearly not a mutualistic relationship (Dila might be stretching the strict scientific meaning of the term in these stories). What is important is his recourse to a biological trope, rather than an ethical or political imaginary; that is, to a non-humanist discourse concerned with imperatives of survival rather than a humanist narrative of victory or justice or liberation. These moments of endosymbiosis are imaginings of radical forms of refuge in which an "advanced" but precarious life form finds a path to survival by piggy-backing on (or slipping into the mode of being of) another, more durable organism. They constitute intensely defamiliarizing reworkings of the colonization of Africa. Witness, for example, the alien species hiding beneath the lake under "Itanda Bridge," who have hijacked human bodies to form a new species. These strange fish-men, whose eyes are yellow discs and whose hands end "in a mess of creepy, long fingers," are hybrid organisms: "Something pumped inside their bellies like a second heart" (52). In this hijacking of the human by the alien colonizer, a psychological entanglement also takes place, in which the human protagonist becomes party to the memory "of a strange world with a yellow sky, that had no sun, no moon, or land. A water world with only one kind of creature, that looked like a cat fish, whose reckless activities had caused apocalyptic evaporation" (53). Endosymbiosis here thus acts to cleverly defamiliarize the colonizer-colonized relation. The aliens' violent commandeering of African bodies is destabilized, on one hand, by the aridity of the colonizers' world, made available for inspection to the colonized, and on the other, by the way they offer an escape route-albeit an extreme one-to the colonized human subject whose existence has become increasingly untenable. These instances of endosymbiosis are traumatic, nonlinear 
forms of transformation within the human organism that can-although they do not always - offer lines of flight from intolerable situations. I bring them up here to highlight the way in which Dila draws on the most brutal aspects of colonial history as a resource for imagining extreme forms of survival emerging from within catastrophe. Indeed, these imaginings of endosymbiosis are clearly informed by the long African history of colonial domination, in which the outright banishment of the catastrophic agent is not (immediately) possible.

Japia's survival is not a straightforward case of endosymbiosis. Yet he too improvises a form of survival in a catastrophic world in which neither overthrow of nor escape from the enemy is an available option. His solution is created via a form of intimacy with the nonhuman. Japia survives the immersive swarm of Miss Doe by becoming the "leafy man" of the title, covered head to toe in orange leaves that enable him to move while surrounded by the "buzzing cylinder" of Miss Doe beyond whose walls he can neither see nor hear (3). It is a form of radical refuge within catastrophe-not a sterilizing, immunizing carapace like the PGCC Hazmat suit but organic, wilting, decaying, permeable, vulnerable.

When Japia evades the PGCC rescue attempt, choosing to survive in the most precarious form within the vampire cloud, it is not a gesture of despair or resignation, but a delinking from the episteme of modern Man-with its attendant notions of progress through domination-represented by PGCC. I would go so far as to say that the story rejects the idea of a "common humanity" in favor of a common earthly precarity: Japia's line of flight is by no means a return to a "simpler," "indigenous," or "pre-vampiric" form of life, but rather, to employ a useful French phrase, a fuite en avant: a "flight forward" into strategic alliances with the nonhuman. If the story ends on a vision of survival reduced to an absolute minimum, as Japia outwits both Miss Doe and PGCC, it does so on a note of defiance. "He would stay hidden, and go to the town for more food only at night. He would work alone to reclaim his village from Miss Doe, for he knew which weapons to use: oranges, and fire" (15). Oranges and fire evoke their own rich evolutionary intertwinements with the human species. Fire is of course the symbol of Prometheus, of the originary moment of becoming human, orange trees a symbol of humankind's earliest ecological interventions into the planet. ${ }^{8}$ These two entities, organic and inorganic, point to the ancient interface between the human and the nonhuman that long predates the industrial revolution.

Fire, oranges, and Miss Doe: three unique forms of human experimentation in geological agency. The first two, fire and oranges, are premodern, suggesting the earliest human forays into geological experimentation. The last is hypermodern, an outgrowth of instrumental reason, suggesting an attempt to subdue an ecosystem to human mastery. I do not think the invocation of fire should be read as a gesture toward a heroic narrative. In the hands of a more conventional writer, the story might have taken the form of an environmental morality tale in which, in Michael Pollan's words, "Nature pays Man back for his transgressions, usually in the coin of disaster" (xxv). But, as Dila narrates it, there is a switch of gear: rather than Man standing outside of or apart from Nature, we find intimations of the human co-evolution with the nonhuman. To invoke fire and oranges as weapons with which to combat Miss Doe is to suggest that there are futures other than that inaugurated by the scientific and industrial revolutions of Europe into which 
ecological entanglement might take the human, alternate ontologies in which the human and nonhuman are not locked into a fatal antagonism.

\section{THE AFRICAN VAMPIRE}

In invoking the vampire, "The Leafy Man" speaks to a long history of colonial and postcolonial misadventure on the African continent in which environmental catastrophe merges seamlessly with medical adventurism and capitalist depredation. As I've suggested, this is no conventional allegory of vampiric extraction. It is rather a hybrid, syncretic genre that cobbles together generic fragments from both Western and African traditions. While I have thus far been reading "The Leafy Man" as refiguring the Euro-American genre of vampire fiction, it also falls, as I suggested at the start of this essay, into an entirely separate tradition of autochthonous African vampire stores that draw their vocabulary from Western biomedical technology.

A body of early twentieth-century East and Central African rumors and folktales-emerging entirely independently of the European tradition-imagining white settlers extracting blood from black Africans constitute an Ur-text for the African vampire. These stories are fixated not on a waning aristocratic class of highly individualized and sexualized beings, but on vats and pipes and needles and pills, on ambulances and uniforms: the bureaucratic paraphernalia of the European settler class. In these stories, white doctors (and other members of the colonial bureaucracy) are said to consume the blood of black people-blood that is turned into pills, stored in vats, drained through pipes, and ultimately consumed to nourish the white man. In one set of stories, white people are said to have taken blood from Africans, transported them to hospitals, and there turned their harvest into edible red capsules. These pills were consumed to provide the nourishment they required to survive in Africa.

I draw these portraits of the "African vampire" from a series of folktales and rumors discussed in Luise White's Speaking with Vampires. The stories White documents are not "vampire stories" in the sense of working within the European tradition beginning with Polidori's The Vampyre (1818). A number of local terms-mumiani, wazimamoto, banyana-were given to the bloodsucking humanoid being that appears in these stories, which originated during the First World War and took shape as Western medical technology-in particular transfusion-infiltrated colonial spaces. Many of the vampire tales White chronicles speak to the forms of biomedical power that in complex ways accompanied imperialism. In Nairobi, wazimamoto-who resembled ordinary men-entered the houses of women as they slept, carrying "a sort of sucking rubber tube that they would stick in your hands while you were asleep and draw the blood out of your body and leave you there and eventually you would die" (106). Other stories from the northeast coast of Kenya describe a fire engine or medical vehicle that "patrolled the streets in the dead of night ... and should it come upon a straggler, draws from his veins all his blood with a rubber pump, leaving his body in the gutter limp and drained" (108). In Kampala, it was said that when trucks put on their sirens, they were out to catch people and extract their skeletons; in Western Kenya, victims were said to be "injected in the head with a bloodsucking needle" (115). 
There is little here that bears comparison with the iconography of the European vampire tale. ${ }^{9}$ The African vampires White describes are fundamentally bureaucratic creatures au fait with the latest in modern technology, beings that are "internationalized, professionalized, supervised, and commodifying" (29). ${ }^{10}$ If the European vampire is typified by his fangs-an extrusion of his animalistic, penetrative, quasi-sexual personality, the African vampire is characterized by the prosthetic nature of his extractive devices, typified by the syringe: cold, metallic, technical, impersonal.

How does this body of African vampire stories link up with Dila's far more self-consciously fictional creation? First, they depict a world in which the vampire has attained dominance: a world from which the extermination of the vampire is not an immediate possibility. Second, these stories are to a large extent stories about invasive Western medical technologies. As White argues, they form counterpoints to imperial medical writing. Medical writing and vampire stories featured the same components-clinics, injections, anesthetics-but saw them from radically different perspectives. While medical writing situated itself firmly in the realm of colonial science, the African vampire genre depicted "the world as seen by people who saw boundaries and bodies located and penetrated" (5). These stories were not misreadings of medical procedures, but rather "a way of talking about the world that both parodied the new technologies and showed the true intent behind their use" (29).

It is worth noting here that Dila's story is most likely drawn from a recent instance of Western biotechnological intervention in Africa, in which genetically modified mosquitos were introduced into Uganda (and Brazil) to combat the Zika virus. ${ }^{11}$ The story is obviously not "about" this episode in any obvious mimetic way. Rather, as White notes regarding African vampire rumors, Dila uses this historical episode as a point of departure: Dila's fantastical elaboration of this historical episode allows him to explore the broader implications of life, both human and nonhuman, in the African Anthropocene. White argues that African vampire tales functioned to endow their tellers with a sense of agency in a world in which boundaries were repeatedly transgressed: they are "stories ... in which Europeans get the upper hand. They were not necessarily smarter than Africans, but they had better tools, more power, and, most especially, better drugs" (114). Dila's story also concerns imaginative agency, but in a far more literal way, depicting both the obliteration of the European "rescuers," but uniquely African forms of survival, resilience, resourcefulness, and knowledge. This is a complex figuring of agency that does not fit into a straightforward romance of anticolonial resistance. Dila is not interested in the simple overthrow of one colonial regime of "Man" with another postcolonial one (we must remember that PGCC enters Uganda with the collusion of the Ugandan state). Rather, the story advocates a delinking from a certain Western conception of human flourishing as connected to technological domination over the nonhuman world. It is not interested in forms of nativism (Japia rejects a blind adherence to traditional medicine, instead advocating experimentation and syncretism), but rather in the pragmatic reformulation of the human-drawing on local knowledge and experimentation rather than simple tradition-as an entity enmeshed within a world of animate agents. 


\section{CONCLUSION}

There is a striking passage in Bram Stoker's Dracula where Jonathan Harker gazes on the supine Count in his coffin. "This was the being," he writes, "I was helping to transfer to London, where, perhaps, for centuries to come he might, amongst its teeming millions, satiate his lust for blood, and create a new and ever-widening circle of semi-demons to batten on the helpless" (67). Harker's thought is eerily thrilling for its biological vision of fin de siècle London, reduced from the pinnacle of the imperial order and made into a food source. Harker sees through the Count's aristocratic mystique to reveal an organism that preys on the human species, impertinently converting the human subject into a mere foodstuff. Harker's fear-never realized in Stoker's novel-is that, in taking on the role of apex predator, Dracula might displace the human being from its enthronement at the pinnacle of the food chain. Behind or beyond the aristocratic mystique of the vampire-the sexual perversity, the insatiable appetite-is an ecological vision that displaces the imperial British subject from its centrality.

I conclude by returning to this seminal European vampire because contained in this passage are the seeds of Dila's ecological vision. The supplanting of the human from ecological primacy that Harker intuits in the figure of Dracula is the general condition of the human species in the age of the Anthropocene. It is possible to see an evolutionary arc in the genre from Stoker to Dila in which Count Dracula, transplanted to the age of human-engineered environmental catastrophe, yields a being as all-pervadingly catastrophic as Miss Doe. Stoker's novel is not particularly interesting in developing the ecological implications of Harker's insight and instead pursues, with horrified fascination, Dracula's sexual and racial otherness. "The Leafy Man," by contrast, is less interested in racial difference (although PGCC is associated, to be sure, with a kind of epistemic whiteness) than in a common ecological predicament that must be survived. By supplanting the human subject from its sovereignty, it forces us to think of ourselves as a species among other species, as sharing a common vulnerability: that is, to think of ourselves ecologically.

Indeed, as Japia contemplates the dominance of Miss Doe in Abedo, a weakness within her species' hegemony emerges. Once Miss Doe has drained the environment of its sanguinary resources, she will starve. Miss Doe disobeys a basic principle of ecological survival: that the parasite must preserve its host, the predator its prey. There is a fundamental principle of limits governing the animate, ecological order imagined by Dila. Ecological entities that pay no heed to these limits will obliterate not only their environments, but themselves.

\section{ACKNOWLEDGEMENTS}

This article was written on a Postdoctoral Research Fellowship at the University of Johannesburg.

\section{NOTES}

1. Boehmer has written of the way in which, in the scouting manuals of Baden Powell, the colonizing subject was enjoined to discipline his body to ward off intrusions, to keep orifices closed, and make corporeal boundaries impermeable. Yet this 
same body drew nourishment and sustenance from the very others against whom it warded its boundaries. More generally, Boehmer sees the figure of the vampire as arising from a sense that empire is spread too wide and thin, rendering its body vulnerable to perforation. Says Boehmer: "If empire is defined as a set of practices designed to keep the imperial body politic intact, and to ensure its growth, then imperialism in its forms of both ambition and anxiety might be said to be founded upon vampire-like lusts and aversions.... Empire fears always the pollution, disorder and unmanning that might come from without, yet marks of invasion, of penetration, are always already visible upon the so-called inviolable imperial body" (vii).

2. One could well launch a feminist critique of Dila's story for the way in which it marks the feminine (and unmarried) Miss Doe as the site of an uncontrollable and catastrophic reproductive potential.

3. See Armstrong 137-53.

4. Stoker's Count Dracula does metamorphose, turning into a bat, a wolf, and a gaseous cloud. However, he is anomalous: the convention surrounding the EuroAmerican vampire is that he or she is confined to human form.

5. Moonsamy notes that, while both concepts are invested in futurity, the "African postcolonial project lies contrary to the idea of sterile utopias" that she sees as promulgated by Western SF. Moonsamy goes on to argue that much recent African SF accordingly "seeks to contaminate the notion of utopia itself" (330). There is a parallel here with Roberto Esposito's argument that the contemporary period is governed by a paradigm of immunity. "What matters," he writes, "is to impede, to prevent, to fight, with every means available, the diffusion of contagion wherever it occurs" (6).

6. I provide a more extensive theory of mutation as an aesthetic and political logic in a discussion of Johannesburg science fiction (see Wright, "Mutant City"). I also discuss how this, the logic of mutation, impacts South African instantiations of the vampire-in many ways figures for a decaying white identity-in "Ecologies of Blood."

7. In her own work, Haraway coins the term "Cthulucene" to describe a radically non-anthropocentric and post-humanist ethics appropriate to surviving and resisting the various concatenated epochs we inhabit: the Anthropocene, the Plantationocene, the Capitalocene. Haraway derives Cthulucene from the roots kairos (now) and chthonos (of the earth). (She specifically distances the terms from H. P. Lovecraft's Chthulhu.)

8. Human beings are of course a uniquely fire-wielding species, and environmental historians have shown that fire marked the point of humankind's first experiments in large-scale geological agency. On the role of fire in the development of the human species-as a fire-wielding species-and the pyrophobia of European modernity, see Clark and Yusoff.

9. White uses the European term vampire, she explains, because "[n]o other term depicts the ease with which bloodsucking beings cross boundaries, violate space, capture vulnerable men and women, and extract a precious bodily fluid from them. No other term conveys the racial differences encoded in one group's need for another's blood. Europe's literary vampires were a separate race, which fed, slept, and reproduced differently from humans."

10. White suggests that the African vampire can be seen as a synthesis of witchcraft and colonialism. Like the witch, he moves about at night. Unlike the witch, however, this vampire wears identifiable uniforms, carries the equipment of Western medicine, has no familiars, is not rooted in local society, uses mechanized transport, and engages in bloodsucking not as a "personal malice but a job" that imperils everyone.

11. See LaFrance; Specter. Both commentators warn against alarmist narrativizing of these mosquitos, highlighting the severity of the disease it is intended to combat. 


\section{WORKS CITED}

Arata, Stephen D. "The Occidental Tourist: Dracula and the Anxiety of Reverse Colonization." Victorian Studies, vol. 33, no. 4, 1990, pp. 621-45.

Armstrong, Nancy. How Novels Think: The Limits of Individualism from 1719 to 1900. Columbia UP, 2005.

Boehmer, Elleke. "Foreword: Empire's Vampires." Transnational and Postcolonial Vampires, edited by Tabish Khair and Johan Höglund, Palgrave MacMillan, 2013, pp. vii-ix.

Browde, Daniel, and Joshua Ryba. Rebirth. Reach Publishers, 2012.

Clark, Nigel, and Yusoff, Kathryn. "Combustion and Society: A Fire-Centred History of Energy Use." Theory, Culture \& Society, vol. 31, no. 5, 2014, pp. 203-26.

Dila, Dilman. A Killing in the Sun. Black Letter Media, 2014.

Ghosh, Amitav. The Great Derangement. U of Chicago P, 2016.

Haraway, Donna. "Anthropocene, Capitalocene, Plantationocene: Making Kin." Environmental Humanities, vol. 6, 2015, pp. 159-65.

LaFrance, Adrienne. "Genetically Modified Mosquitos: What Could Possibly Go Wrong?" Atlantic, 26 Apr. 2016, https://www.theatlantic.com/technology /archive/2016/04/genetically-modified-mosquitoes-zika/479793/.

Latour, Bruno. "Agency at the Time of the Anthropocene." New Literary History, vol. 45, 2014, pp. 1-18.

MacKenzie, John M. "Empire and the Ecological Apocalypse: The Historiography of the Imperial Environment." Ecology and Empire: Environmental History of Settler Societies, edited by Tom Griffiths and Rodin, Keele UP, 1997, pp. 215-28.

Moonsamy, Nedine. "Life Is a Biological Risk: Contagion, Contamination and Utopia in African Science Fiction." Cambridge Journal of Postcolonial Literary Inquiry, vol. 3, no. 3, 2016, pp. 329-43.

Moretti, Franco. “The Dialectic of Fear." New Left Review, vol. 136, 1982, pp. 67-85.

Morton, Timothy. The Ecological Thought. Harvard UP, 2010.

Omelsky, Matthew. "'After the End Times': African Postcrisis Fiction." Cambridge Journal of Postcolonial Literary Enquiry, vol. 1, no. 1, 2014, pp. 33-49.

Pollan, Michael. The Botany of Desire: A Plant's Eye View of the World. Bloomsbury, 2003.

Specter, Michael. "The Dangerous Conspiracy Theories About the Zika Virus." New Yorker, 25 Feb. 2016, http://www.newyorker.com/news/daily-comment /the-dangerous-conspiracy-theories-about-the-zika-virus.

Stoker, Bram. Dracula. 1897. Penguin Books, 1994.

Tsing, Anna Lowenhaupt. The Mushroom at the End of the World: On the Possibility of Life in Capitalist Ruins. Princeton UP, 2015.

White, Luise. Speaking with Vampires: Rumor and History in Colonial Africa. U of California $\mathrm{P}, 2000$.

Wright, Timothy. "Ecologies of Blood in Johannesburg Vampire Fiction." Safundi: The Journal of South African and American Studies, vol. 17, no. 4, 2016, pp. 384-406.

_. "Mutant City: On Partial Transformation in Three Johannesburg Narratives." NOVEL: A Forum on Fiction, vol. 51, no. 3, 2018, pp. 417-37. 
Copyright of Research in African Literatures is the property of Indiana University Press and its content may not be copied or emailed to multiple sites or posted to a listserv without the copyright holder's express written permission. However, users may print, download, or email articles for individual use. 